\title{
Exploitation of coastal and marine resources along Tomini Bay: Livelihood base versus concession rights
}

\author{
Eksploitasi sumber daya pesisir dan laut di Teluk Tomini: Basis mata \\ pencaharian versus konsesi
}

\author{
Muhammad Obie \\ Faculty of Tarbiyah and Education, Institut Agama Islam Negeri Sultan Amai Gorontalo \\ Jalan Gelatik No. 1, Gorontalo City, Gorontalo 96135 \\ E-mail: obiclimber@gmail.com
}

\begin{abstract}
The abundant coastal and marine resources in Tomini Bay are constantly contested between various actors, namely the state, private entities, multilateral institutions, NGOs and the indigenous community, the Bajo Tribe. On the one hand, the Bajo Tribe utilises coastal and marine resources as a livelihood base, while, on the other hand, private entities with concession permits from the state seek to take maximum benefit for their economic prosperity. The research aims to analyse the concession of coastal and marine resources and its implications on the livelihood base of the Bajo Tribe. Livelihood base is defined as a resource or asset that can be utilised to fulfil a community's need or survival. This research employed a critical theory paradigm with a strategy of case study and ethnography. The data collected were qualitative data. Data analyses were conducted using a qualitative approach. The findings revealed that the concession of fishponds and the timber industry has caused Tomini Bay, initially rich in coastal and marine resources, to experience severe environmental damage. This condition has disrupted the livelihood base of the Bajo Tribe. The Bajo Tribe's livelihood, which is fully dependent on coastal and marine resources, is threatened. The further impact lies in the fact that most Bajo people still live below the poverty line. To maintain the sustainability of coastal and marine resources and ensure the livelihood base of the Bajo Tribe, the utilisation of local wisdom becomes a very astute choice.
\end{abstract}

Keywords:coastal and marine resources; livelihood base; concession; Bajo Tribe; local wisdom

\begin{abstract}
Abstrak
Sumber daya pesisir dan laut yang melimpah di Teluk Tomini tidak henti-hentinya menjadi rebutan berbagai aktor, yakni negara, swasta, lembaga multilateral, NGOs, dan masyarakat adat, komunitas Suku Bajo. Di satu sisi masyarakat adat, komunitas Suku Bajo, memanfaatkan sumber daya pesisir dan laut sebagai basis livelihood, sementara swasta yang telah memegang izin konsesi dari negara berusaha mengambil manfaat sebesar-sebesarnya untuk kemakmuran ekonomi. Tujuan penelitian ini adalah menganalisis konsesi sumber daya pesisir dan laut serta implikasinya terhadap basis livelihood komunitas Suku Bajo. Basis livelihood didefinisikan sebagai sumber daya atau asset yang dapat dimanfaatkan untuk memenuhi kebutuhan atau kelangsungan hidup. Penelitian ini menggunakan paradigma teori kritis dengan strategi studi kasus dan etnografi. Data yang terkumpul berupa data kualitatif. Analisis data dilakukan melalui pendekatan kualitatif. Hasil penelitian menunjukkan bahwa konsesi tambak dan industri kayu telah menyebabkan Teluk Tomini yang awalnya kaya sumber daya pesisir dan laut, mengalami kerusakan lingkungan yang sangat parah. Kondisi ini menyebabkan krisis basis livelihood komunitas Suku Bajo. Komunitas Suku Bajo yang sepenuhnya menggantungkan hidup pada sumber daya pesisir dan laut menjadi terancam. Dampaknya yang lebih jauh, komunitas Suku Bajo tetap hidup di bawah garis kemiskinan. Untuk mempertahankan keberlanjutan sumber daya pesisir dan laut, sekaligus menjamin basis livelihood komunitas Suku Bajo, pemanfaatan kearifan lokal menjadi pilihan yang sangat bijak.
\end{abstract}

Kata kunci: sumber daya pesisir dan laut; basis livelihood; konsesi; komunitas Suku Bajo; kearifan lokal

\section{Introduction}

Legal communities along the coast line straditionally manage coastal and marine resources, which is known as marine customary rights. As indigenous people, Bajo Tribe has ulayat right in Tomini Bay, which has been going on for generations and respected by its people. Since the 1800 s, Bajo Tribe has been dwelling along Tomini Bay, even though it was only inaugurated as an administrative village by Dutch Colonial Government later in 1901 (Obie et al. 2014). Bajo Tribe was known as sea nomads due to its wandering lifestyle, yet ultimately chose to settle above sea level along Tomini Bay. 
Initially, the village of BajoTribe only consisted of soppe-soppe (big boats where Bajo people lived). Prior to its official inauguration, the village was only a temporary shelter. They were always moving aroundand catching fish somewhere for a month and then going elsewhere. They moved around Tomini Bay in groups of five to ten soppes and stopped at the islands' coasts around there. The coastlines they occupied contained abundant coastal and marine resources, such as fish, coral reefs, seagrass beds, and other marine products (Zacot 2008).

Coral reefs alongTomini Bay have been famous for a long time because of its beauty. It is also known as the heart of the world's coral triangle. Along this bay, numerous species of fish, marine mammals, turtles, corals, sponges, and other organismslive (Block 2009). A UN body, UNESCO, set Tomini Bay as one of the world's riches that should be protected due to its promising potential, including magnificient under water beauty and abundance of fish. Yusron \& Edward (2000) studiedwater condition and biodiversity inTomini waters and mentioned that the availability of reef fish in these waters wasincrediblyabundant. The waters of Tomini Bay, with a coastline length of approximately $1,350 \mathrm{~km}$ and encompassing an area of about $137,700 \mathrm{~km}^{2}$, boastits potential of sustainable fish resources for about 590,620 tons per year. The abundant coastal and marine resources in Tomini Bay attractedvarious actors to obtain access to get some benefits from it. However, policy makers, as the representative of the state,also undoubtedly raced toward formulating some regulations to organize its exploitation.

Various regulations and policies related to the management of Tomini Bay directly intersect with the interests of indigenous people, BajoTribe. The Bajos maintain a close relationship with their surrounding natural environment, knowing the ecological functions of mangroves as a place to lay eggs and fish development. In addition, mangroves also reduce wind exposure, prevents erosion, and provide a habitat of Sulawesi's endemic monkeys (macaca) and some reptiles. Furthermore, Bajo Tribe also understands the economic functions of mangroves, namelyas firewood, building materials, fish nets' dye, cosmetics, and traditional medicines, as well as possesses the knowledge on how to find numerous types of fish, shrimps, crabs, honey bees, and other animals. They fully understand that mangrove degradation causes coastal erosion and a decline in fishstocks (Block 2009, Damanik \& Djamaludin 2012).

Conflict occured when coastal and marine resources' benefitswere converted through some concession permits to private parties (Obie et al. 2014). Bryant \& Bailey (1997) stated that there are five actors interested in natural resource management, namelythe state, private entities, multilateral institutions, NGOs, and grassrootsociety (indigenous/local communities). They asserted that the concession of natural resources to private parties can lead to complex conflicts which do not only involve the local community and government, but also involve private entities who have obtained the concession rights. Coastal and marine resources, which were originally freely accessible to BajoTribe (as common pool resources), are turned into private properties. Such problems are also the root of environmental damage, which is commonly called'tragedy of enclosure'. It refers toa tragedy instigatedby state and private domination which causes local people's access to their own resources to be increasingly restricted. According to Dahrendorf (1959), the actors have different authorities; some are in superordinate positions and the other are the subordinates. Each actor has substantial interest and goes to opposite directions; hence, conflictscan not be avoided. Meanwhile, Ostrom and Schlager (1996) with the concept of bundle of rights stated that concession rights lead to a restricted aceess to BajoTribe over the coastal and marine resources which have been their livelihood base for generations.

Research on natural resource conflicts has been widely practiced by previous experts. Obie et al. (2014) studied ethnic conflict along the coastline of Tomini Bay to identify several types of conflicts, namely conflict of authority, conflict of knowledge, and livelihood conflict. Still surrounding the conflict in Tomini Bay and the contestation of marine and coastal ulayat rights of Bajo people, Obie (2015) concluded that the closure of territorial access and territorialization in coastal and marine resource management resulted in the loss of Bajo community's citizenship as indigenous 
peoples. Research on natural resource conflict was also conducted by Rahmawati (2013) about forest resource conflicts. She managed to give birth to a new theory called 'social resilience theory' on the contestation of forest resources. Zainuddin's (2012) research on competing authorities in the forest concluded that conflicts occurring in such area arenot stand-alone conflicts. The conflicts that occuredwere prominent and hidden by temporal dynamics. Tangketasik's (2010) research on some new negotiation spaces to obtain the control of forest resources concluded that the dynamics of forest's claim of authority and power relations which are established between parties are influenced by individual's authority claimbased on state and customary law. Antoro's (2010) study on the topic of natural resource conflicts in mining areas concluded that the issuance of iron-sand-mining policies in coastal areas to earn local revenues did not only spark conflict between government, civil society, and private entities; but also threatened the sustainability of knowledge evolution, ecosystems, and society existence. Further research by Prayogo (2008) on the topic of conflict between corporations and local communities in geothermal industry suggested that the main cause of conflict between corporations and local communities is inequality and injustice. Government institutions, which are normally expected to be neutral, possess legitimacy with their regulations and become the judges; however, they are proved incapable of performing this task.

Examining previous research findings which focused more on resource management's conflicts, this study focuses more on the analyses of livelihood base. The author intends to analyze the concession of coastal and marine resources and their implications on BajoTribe's livelihood base. Livelihood itself refers to the ways in which a person meets his needs or survival (Chambers \& Conway 1992). The UK Department for International Development (DFID) (1999) defined livelihood as the capability, asset, and activity necessary for survival. In parallel, Ellis (2000) described livelihood as an asset, activity, and access which together determine the life of individuals or households.

Therefore, coastal and marine resources as the livelihood base of Bajo Tribe can be defined as resources or assets which can be utilized to meet the needs or survival of Bajopeople. BajoTribe exploits the coastal and marine areas of Tomini Bay as their livelihood base, as an area to catch fish and look for other marine products. When the coastal and marine resources are exploited by private entities which obtained concession rights, a livelihood crisis is inevitable. Concession rights, in this case, refer to the Law of the Republic of Indonesia Number 30 Year 2014 concerning the Administration of the Government. It stated that the concession refers to the decision of a competent government official as a form of approval or agreement for any agency and/or government officials to manage public facilities and/or natural resources and other types of management in accordance with the provisions of the regulations. The author defines concessions rights in this study as the granted permit from the state or itsapparatus which authorized any corporations and/or individuals to exploit coastal and marine resources along Tomini Bay.

\section{Research Method}

This study employed a critical theory paradigm under the consideration that Bajo Tribe as one of the actors sufferingfrom restrictions and loss of access to coastal and marine resources which have been their livelihood base for generations. Meanwhile, the private entities obtained concession rights to manage coastal and marine resources (Guba \& Lincoln 2000). Selecting critical theory paradigm was also based on the consideration that this study sought to analyze the implications of concession rights for coastal and marine resources on the livelihood base of Bajo Tribe.

This research employed qualitative approach with case study and ethnography method. The case study method intended to make the case study more focused (Surakhmad 1982). This research's case study was the concession rights of coastal and marine resources in Tomini Bay. Meanwhile, ethnographic methods were employed to understand BajoTribe's views on the impact of concession rights on their livelihood base (Spradley 2007). The collected data were mostly primary data obtained through in-depth interviews and passive participation (Sugiyono 2009; Moleong 2007). Informants, as the source of qualitative data, were selected through snowball techniques. The researchers first 
interviewed some key actors (village heads), then asked them to mention other actors whom they perceived to have some understanding about the research problems. Thus, the number of informants were snowballing (Sugiyono 2009). To support the qualitative data, the researchers also collected some secondary data, namely previous research and government regulations/laws related to natural resource management.

\section{Results and Discussions}

\section{Consession rights of coastal and marine resources}

Natural resource concessions became one of early development strategies during the New Order era to improve the country's economy. In many cases, this strategy raisedsome fundamental issues, because environmental damage it brought about was inevitable. Particularly in Tomini Bay, the influx of investment destroyed the mangrove forests in the region. There were two important momentumwhich signaled the beginning of coastal and marine resources' destructionalong the bay (Obie et al., 2015). First, the entry of sometimber companies to utilize the coastal areas in Tomini Bay as loading and unloading operation areas, as well as building camps and corporate offices. Its entry in 1977 cleared the mangrove forests, while BajoTribe livingaround the area was evicted. PT. MBT was the first logging company to exploit the coastal areas of Tomini Bay after obtaining a concession license in the form of Forest Concession (HPH). When PT. MBT closed down its business in Tomini Bay in 1983, PT. WS continued the project in 1987 and caused 71 ha of mangrove forest along the coastline of Tomini Bay to disappear. The mangrove forests were converted into camps, offices, and harbors for the loading and unloading decks of the company's vessels. The second momentum was signaled by the opening of salt farming ponds under for a concession in the form of Right to Cultivate (Hak Guna Usaha-HGU) decreed by Gorontalo District Government. It also occurred in 1977 and obliterated 70 hectares of mangrove forests. The salt farming business was further expanded along with the issuance of Governor Decree of KDH Level I North Sulawesi 200/1996 concerning 12,752 hectares' land provision for pond pattern's transmigration site in Gorontalo regency. In its furtherdevelopmet, since the 1980s, the salt ponds have graduallyshifted intoshrimp and milkfish ponds.

The concession of coastal and marine resource areas in Tomini Bay got more complicated in the era of regional autonomy. Precisely in 2012, PT. KG operated under $H G U$ palm oil plantation in Popayato mountain range. The company acquired a concession right of 30,000 hectares for a period of 25 years. Meanwhile, its subsidiary, PT. JAD, bagged a Logging Permit (IPK) for five years period for logging prior to planting the palm oil trees. The resultswere thousands of $\mathrm{m}^{3}$ logsdumpedalong the coastline of Tomini Bay.

"There were logs within the area. It was a pity if [it was] not processed. [It would be] damaged. [Moreover] it could be considered as an asset belonged to regional government. Therefore, PT. JAD, which held IPK, processed the logs. Then PT.KG planted the palm oil trees"(Suhardi 2013).

Both logging industry and shifting functios of salt ponds into shrimp or milkfish ponds increasingly exacerbated the damage of mangrove area. The clearing of mangrove area became more widespread, although the mangrove forest itself had many benefits. Dahuri et al. (2001) described that mangrove forest ecosystem hasits own relationship mechanism with other types of ecosystem, such as seagrass and coral reefs. As a producer of organic materials which are the main food chain in coastal ecosystems, mangrove litter which is fallen into the water will be a good substrate for bacteria and at the same time, help the process to form detritus from the leaves. Furthermore, the detritusbecomesfood for various animals, such as worms and small shrimp; eventually, these animals also become food for larvae of fish, shrimp, crabs, and other animals. In addition, the mangrove area is also a nursery ground for animals in juvenile stage and a spawning ground for some animals in some waters, such as shrimp, fish, and shellfish.

Saparinto (2007) stated that extensive mangrove conversion into ponds can lead to a decrease in fisheries production in the surrounding waters. These ponds also allegedly affect theestuary and ocean around it; for instance, it may cause a decline in shrimp production as a result of diminishing 
mangrove forest area. Accordingly, Martosubroto and Naamin (1977) suggested that converting mangrove forests into large-scale ponds destroy these forests' resources and in the end, it may result in disconnection of ecological and biological processes which lead to a decline in water productivity. In addition, clearing mangrove forest areas can cause health problems. It is also proved that mosquito populations increase as a resultand even lead to vulnerability to malaria outbreaks.

As a result of the concession, Tomini Bay which was originally rich in coastal and marine resources, suffered severe environmental damage. The largest mangrove forest bufferedalongTomini Bay was threatened to its extinction. The mangrove damage along the area was very severe, as thousand hectares of mangrove forest areawere cleared to open some ponds. Ironically, the mangrove forests, which were cleared for the ponds, wereactually parts of conservation areas and protected forests.

"More than 50 percent of mangrove areas within the conservation area of Tomini Bay were converted into ponds. Generally, those ponds belonged to cukongs ( roughly means "broker") from South Sulawesi who took advantage of the locals. Several influential figures, including high-ranking officers, also facilitated mangrove openings. Some of them even directly owned those ponds filled with milkfish and shrimp." (Paino 2013).

This reality reinforced Bryant \& Bailey's (1997) thesis that ecological issues are not technical, but rather as a result of the existing political and economic order and political process of the actors with their respective interests, which is called politicised environment. The dominant actors are generally the state and private entities which lead to tragedy of enclosure. It refers to the tragedy instigated by the domination of state and private entities which constrainedthe local community's access to the exploitation and management of resources. Along with debilitating their access, the communities are further marginalized.

Mangrove damage was increasingly out of control, as more people from BugisTribe entered Tomini Bay (Obie et al. 2015). Bugis people were smart to take advantage of the weakness of the locals who were not proficient in managing ponds. Bugis people, who initially played a role to help local people manage the ponds, gradually possessed the ownership of the ponds through buying and selling lands, on the account of their capital and expertise. Along with the success of the Bugis people in managing the pond, the claim of ownership for mangrove areas by locals from GorontaloTribe were increasingly rampant. Gorontalo Tribe who claimed ownership over mangrove areas then cleared the areas, then sold them to Bugispeople to be turned into new ponds.

The destruction of mangrove areas, which were turned into ponds, was massive, even involving village administration and sub-district governments. Conservation areas, which were supposedly under the authority of the central government, could be converted to ponds merely using two permits from village head or sub-district head. Shrimp and milkfish ponds originally were salt farming areas and were opened under the permission from the village head or the local sub-district head.
"Ponds' owners, who identified mangrove and possible attempts to process it, make an appeal through a group inquiry to the village head to obtain a permit. The appeal is then brought to the sub-district head for another permit. So, pond farmers have two kinds of permit, from the village and sub-district. To obtain both, a business owner only needs to pay IDR 500,000 (five thousand rupiah) as the administration cost." (Kasim 2013).

Another way used by Bugis people to open a new pond was by asking Gorontalo people to form a group to clear the mangrove forests. After the mangrove area was ready to be turned into ponds, local people who did not have the expertise to manage them sold it to Bugis people with at a bargain (Obie et al. 2015). One of the pond owners from South Sulawesi was a police officer of Pohuwato.

\footnotetext{
"This police officer is quite successful in his pond business. He just bought some heavy equipment and a Toyota Hilux. The equipment is employed to manage a new pond, either his own or renting it for other business owners. While the Hilux is used to transport production materials and pond's yield during harvest." (Kasim 2013).
} 
Local governments seemed to legitimize the occurring practices by deliberately letting the land plotting to run rampant at the mangrove areas. During the 2000s, especially under administration of Regent $\mathrm{ZH}$ who was aBugis man, there was a massive opening of new ponds in conservation areas and protected forests. Meanwhile, the local government did nothing to prevent widespread mangrove destructionand even made some recommendations to open a new pond.

"These shrimp and milkfish ponds are opened under the recommendation of former Regent ZH and current Regent SM.” (Woyan 2013).

The process of land clearance for a new pond through this kind of 'game' became a commonplace in Tomini Bay. Local governments even supported the destruction of mangroves in this area. It was indicated by their help to provide facilities and infrastructure to the business owners, as well as the construction of government offices at the protected forest areas. Some of the actors involved in Tomini Bay were local politicians.

\footnotetext{
"One of the leaders in Pohuwato's House of Representative (HoR) during 2009-2014 was known to own a pond. Another owner was a HoR member for two periods (2004-2009 and 2009-2014) from Partai Bulan Bintang. One of Golkar's politicians also owned some ponds, as well as a member of both PPRN and HoR in Pohuwatoin 2009-2014." (Kasim 2013).
}

Associated with the concept of distribution of authority (Dahrendorf 1959) which divides authority between superordinates and subordinates, the destruction of coastal and marine resources along Tomini Bay was actually instigated by state authority by granting concession rights to private entities, referring to both pond businesses and timber companies which used the bay as the company's operational area. Unlike state authorities which are legitimized by the laws and government regulations, local authority merely derived its power from tradition and histories which were inherited from generation to generation.

Conflicts cannot be avoided when two authorities meet in the same area. According to Dahrendorf, it is because both authorities have conflicting interests. However, local authorities in subordinate positions should be the subjects to the state inits superordinate position. Pond operations and timber companies exploiting the coastal and marine resources along Tomini Bay confirmed the weakness of local authorities against state authorities. States with their law-based legitimacy have a formal legal basis to protect and exploit coastal resources by granting rights to private entities. The helplessness of subordinated local authority against the superordinate one paved the way for private concessionholders to degrade natural resources along the coastline of Tominion a large scale.

\section{The crisis of Bajo tribe's livelihood basis}

Naturally, the potential of coastal and marine resources should have been exploited directly by the people who live surrounding the area, which are generally fishermen. Those potencies should be used to fulfill the fishermen's needs for their daily lives. Fishermen along the coastline benefited from sea riches, namely fish, seaweed, corals, and many others, for their daily needs. Exploiting those potencies in a huge scale to gain economic benefit in order to increase economic growth for the grassroot community has not yet to be done. Meanwhile, for Bajo Tribe, coastal and marine resources are theirmain source of production which is not only related to economic aspects, but also to social and cultural aspects (Obie 2015).

The concession of coastal and marine resources in Tomini Bay devastated the livelihood bases of BajoTribe. The area was a hereditary fishing area for Bajo fishermen; yet, currently it changed its function to a vast pond. However, Bajo Tribe as a fishermen community in general strongly depends on coastal and marine environment. Its good and bad condition directly affect their lives. Hence, it is not surprising that a mutual relationship between Bajo people and natural resources are formed. Changes occurring in the environment cause some disturbance to the balance, because some of environmental components have their functions reduced. Damage to environmental resources in coastal and marine areas is one of the problems faced by Bajo fishermen. 
"Once, when the mangrove forests had not been turned into ponds, we only needed a net to catch fish along the coastline. We didn't need to pay a huge sum of money to sail away to the sea. Now the mangrove areas are destroyed, and the sea is polluted. So, we need to sail away to the deep sea to fish, which inevitably needs more money." (Sirulah 2013).

The destruction of coastal and marine resources directly affected the availability of fish and other marine products as the source of Bajo fishermen's economy. They said that since mangrove forests were converted into ponds, it got harder for them to obtain adequate catch. When the mangrove forests were still thriving, they easily caught a lot of fish.Within one hour since they set a net along the coastline to catch fish, their boatswere almost full already. Now those good times have passed, along with the destruction of mangrove forests in their region.

\footnotetext{
"Once upon a time, [if we wanted to] catch fish, we only needed to go to our backyard and were able to obtain tons of fish. Now it is not like that anymore. Everything belongs to the ponds, so we face difficulties to catch fish in order to meet family needs." (Pasandre 2013).

"Way back then, Bajo fishermen could catch tons of fish along the coastline. Now, even if we sailed to $100 \mathrm{~km}$ beyond the coastline, we merely catch $5 \mathrm{~kg}$ of fish each day, at most" (Sompah 2013).
}

The environmental changes caused by the destruction of the coastal and marine areas threatened the future of Bajo people who were fully dependent on coastal and marine resources. It is in line with the findings of Akbar's (2005) research which stated that mangroves are not only ecological, but also have a tremendous economic value. Mangroves play a major role in fisheries production in mangrove, coastal, and offshore ecosystems. The availability of mangroves greatly affects the fishermen's catch and socio-economic level of traditional fishermen. This finding is also reinforced by the findings of Bidayani's (2010) research that the worst and polluted water condition for water biota can lead to a sharp decline in fisherman income.

The results of both studies reinforced the fact that ecological changes due to mangrove area concessions resulted in the livelihood crisis for Bajo fishermen. Coastal and marine resource's concessions led to ecological changes which altered the availability of fishery products as the main source of income for Bajo fishermen. In addition, it also affected their income and increased the costto access the resources. The loss of mangrove ecosystems erode the livelihood of Bajo Tribe.

\section{Local wisdom as the solution for sustainability}

Bajo Tribe has local knowledge and wisdom which guarantee the preservation of coastal and marine resources around them. They believe that every ecosystem on the coast and the sea is guarded by a supernatural being in the form of spirits. Mangrove ecosystem is guarded by the spirit of mangroves, coral reef ecosystems are guarded by the spirit of coral reefs, seagrass ecosystems are guarded by the spirit of seagrass, and even the sea is guarded by the spirit of the sea. Bajo people believe that if the sea and coastline's ecosystems are disturbed, then those spirits will unleash their wrath. Therefore, Bajo people are very cautiousin treating their existing ecosystems. They further believe that any diseases occurred among them are caused by the spirits' wrath. Hence, every time there is a sick person among them, the duata immediately gather to identify which spirits caused the disease (Obie 2016). After knowing which spirits cause the diseases, the duata can decide on a way to heal it.

Bajo people believe that the destruction of coastal ecosystems is a disaster for their communities. Therefore, they own a conservation ethic to treat the nature wisely, without excessive exploitation. Pamali is the ethic of Bajo people in building relationships with natural environment. In Pamali, there are inviolable environment ethics. If the rules are violated, the culprit will get katula, which refers to an ancestral punishment for those who violate Pamali, in the form of illness, disaster, or bad luck (Obie 2016). To avoid the wrath of the spirits guarding these ecosystems, the duata often holds customary ceremonies to ward off diseases. Bajo Tribe views natural environment as a part of themselves. They routinely perform customary rituals associated with environment on every cycle of their lives, from birth to death. 
Bajo Tribe feels a sense of belonging to the coastal and marine resources around them. They maintain, protect, and preserve it. In thesettlement zone of Bajo Tribe, mangroves and other coastal ecosystems are well-preserved; while outside their settlement, the mangroves were disappearedand turned into ponds.

"Here, we cooperate with young generation to conduct mangrove zonation. There are protection zone and exploitation zone. Those who cut down mangrove within the exploitation zone, perhaps for firewood, must plant 100 mangrove seeds around the fallen trees. While protection zone does not allow any logging activities" (Sompah 2013).

In addition to its strong customary institutions and the role of duata chief to always oversee citizens' behaviors which destroy coastal and marine ecosystems, the younger generation of Bajo initiated a union of Environmental Awareness Group (KSL) called Paddakauang. This association succeeded ininitiating the formation of village regulations (PERDES) on the protection of mangroves along the coastline of Tomini Bay (Obie et al. 2014).

Bajo Tribe, like other indigenous peoples, has long tradition and expertise to manage the surrounding natural resources. Nevertheless, developing the participationof indigenous peoples in natural resource management has not received serious attention from the government. Accommodating the participation of Bajo people in the management of coastal and marine resources in Tomini Bay is inevitable. With the wide distribution of natural resource areas, especially coastal and marine resources, and limited management and human resources institutions, it is impossible that coastal and marine resources management can work well without community participation. There are several factors which support the effective management of coastal and marine resource areas involving Bajo people. Firstly, the closeness of Bajo Tribe to the existing coastal and marine resources. Secondly, their vested interests in the area which encompass historical, socio-religious, ecological, and economic factors, as well as commitment and awareness. For Bajo Tribe, their involvement in the management of coastal and marine resources is driven by motivation and sense of ownershipin which they feel the sense of belonging to the coastal and marine resources.

The closeness between Bajo Tribe and coastal and marine resources can be clearly seen as they carry outvarious activities at sea. When they catch some fishand look for other marine products, they perform some rituals first.

"[It has been] a tradition for Bajo people. When [we] go to sea, we perform a ritual. The materials for rites includebetel nut, betel leaf,lime betel, and cigarettes. It meant to pleada protection of the Sea Spirit (God) from troubles; and plead to the spirit of sea guard for abundant catch" (Pasandre 2014).

Similar rituals are also performed during marriage ceremonies, childbirth, circumcision, traditional medication, and death ceremony. The rituals display Bajopeople's respect toward coastal and marine natural resources. Because of these cultural values, they protect and conserve coastal and marine resources around their settlements.

\section{Conclusions}

Concession rights of coastal and marine resources in the form of HPH and HGU caused environmental damage in Tomini Bay. The entry of timber company's logging concessionaires, which exploited coastal areas alongTomini Bay as loading and unloading docks, as well as building camps and corporate offices, caused mangrove forests to diminish. In addition, the inclusion of HGU to clearan area for salt farming, under the initiative of Gorontalo regional government, caused 70 hectares of mangrove forest to disappear. Since the 1980 s, the salt farming ponds have gradually shifted into shrimp and milkfish ponds. This changing function further exacerbates the destruction of coastal and marine resources in Tomini Bay. Bajotribe, who was fully dependent on coastal and marine resources, was threatened by the destruction of the coastal and marine resources. Furthermore, they also remained living below poverty line, because the available coastal and marine resources are declining and threatened to extinction. Ecological change created a crisis of their livelihood base. The local 
tribefaced difficulties in meeting their own needs and struggle to survive. Since mangrove forests have been converted into ponds, theyfound it increasingly difficult to obtain adequate catches. Things were different when private enterprises had not entered, as mangrove forests were still thriving, so they easily caughtabundant fish and other marine products. Ecological changes occurring in the sea alteredthe availability of fishery products as the main source of income for Bajo fishermen. Losing mangrove ecosystem eroded the livelihood of Bajo people. To prevent further damage to coastal and marine resources in the future, taking Bajo Tribe's local wisdom into account is indispensable. This is because only BajoTribe possesses the local wisdom to manage the sustainability of coastal and marine resources inTomini Bay.

\section{References}

Akbar AA (2005) Pengaruh kerusakan ekosistem mangrove terhadap sosial ekonomi Pesisir Kalimantan Barat. Thesis, PPs UGM, Yogyakarta.

Antoro KS (2010) Konflik-konflik sumber daya alam di kawasan pertambangan pasir besi: Studi implikasi otonomi daerah (Studi kasus di Kabupaten Kulon Progo Provinsi Daerah Istimewa Yogyakarta). Thesis, SPs IPB, Bogor.

Bidayani E (2010) Analisis ekonomi dampak kerusakan lingkungan terhadap pendapatan nelayan pesisir Tanjung Ular Kabupaten Bangka Barat. Thesis, SPs IPBBogor.

Block DD (2009) Perlindungan wilayah pesisir di Sulawesi: Mencermati pendapat masyarakat pesisir. Warta Teluk Tomini, Edisi 7 Sep-Nov, 1-2.

Bryant RL \& Bailey S (1997) Third World Political Ecology. New York: Routledge.

Chambers R \& Conway GR (1992) Sustainable Rural Livelihoods: Practical Concepts for the $21^{\text {st }}$ Century, Discussion Paper 296. Brighton, UK: Institute of Development Studies.

Dahrendorf R (1959) Class and Class Conflict in Industrial Society. Stanford, California: Stanford University Press.

Dahuri R, Rais J, Ginting SP, \& Sitepu MJ (2001) Pengelolaan Sumberdaya Wilayah Pesisir dan Lautan secara Terpadu. Jakarta: PT Pradnya Paramita.

Damanik R \& Djamaludin R(2012) Atlas Mangrove Teluk Tomini. Gorontalo: Program Teluk Tomini-SUSCLAM

DFID (1999) Sustainable Livelihood Guidance Sheet. London: UK Government.

Ellis F (2000) Rural Livelihoods and Diversity in Developing Countries. Oxford: Oxford University Press.

Guba EG \& Lincoln YS (2000) Paradigmatic Controversies, Contradictions, and Emerging Confluences. In: NK Denzin \& YSLincoln (eds). Handbook of Qualitative Research (Second Edition). California: Sage Publications, Inc.

Kasim S (2013) [Personal communication] Mei.

Lahandu (2007) Analisis kebijakan pengelolaan akses sumber daya alam oleh masyarakat Kaili di Taman Hutan Rakyat (TAHURA), Sulawesi Tengah. Thesis, SPs IPB, Bogor.

Martosubroto P \& Naamin N(1977) Relationship between tidal forest (mangrove) and comercial shrimp production in Indonesia. Mar. Res. Indonesia, 18:81-86.

Moleong LJ (2007) Metodologi Penelitian Kualitatif (Edisi Revisi). Bandung: PT. Remaja Rosda Karya

Obie M, Soetarto E, Sumarti T, \& Saharuddin (2014) Konflik etnis di pesisir Teluk Tomini: Tinjauan sosio-ekologi politik. Al-Tahrir,14 (2):295-318.

Obie M, Soetarto E, Sumarti T, \& Saharuddin (2015) Sejarah penguasaan sumber daya pesisir dan laut di Teluk Tomini. Paramita,25 (1):73-87. 
Obie M (2015) Perampasan hak ulayat pesisir dan laut komunitas Suku Bajo (Kasus pengelolaan sumber daya pesisir dan laut di Teluk Tomini). Dissertation, Sekolah Pascasarjana IPB, Bogor.

Obie M (2016) Perubahan sosial pada komunitas Suku Bajo di pesisir Teluk Tomini. Al-Tahrir, 16(1):153-174.

Ostrom E \& Schlager E (1996) The Formation of Property Rights. In: SS Hanna, C Folke, KG Maler (ed). Rights to Nature: Ecological, Economic, Cultural, and Political Principles of Institutions for the Environment. Washington, DC: Island Press.

Paino C (2013) [Personal communication] Mei.

Pasandre S (2014) [Personal communication] Juni.

Pasandre U (2013) [Personal communication] Mei.

Prayoga (2008) Konflik antara Korporasi dengan Komunitas Lokal: Sebuah Kasus Empirik pada Industri Geotermal di Jawa Barat. Depok: Disertasi, PPs UI.

Rahmawati R (2013) Konflik-Konflik Sumberdaya Hutan di Jawa Barat dan di Kalimantan Barat, Indonesia. Bogor: Disertasi, SPs IPB.

Saparinto C (2007) Pendayagunaan Ekosistem Mangrove. Semarang: Dahara Prize.

Sirulah A (2013) [Personal communication] Mei.

Sompah J (2013) [Personal communication] Mei.

Spradley JP (2007) Metode Etnografi, Edisi II. Yogyakarta: Tiara Wacana.

Sugiyono (2009) Memahami Penelitian Kualitatif. Bandung: CV. Alfabeta

Suhardi (2013) [Personal communication] Mei.

Surakhmad W (1982) Pengantar Penelitian Ilmiah: Dasar, Metode dan Teknik. Bandung: Tarsito

Tangketasik (2010) Antara negara dan tongkonan: Ruang-ruang negosiasi baru dalam penguasaan sumberdaya hutan di Kabupaten Tanah Toraja, Sulawesi Selatan. Dissertation, PPs UI, Depok.

Tarigan H (2014) Peluruhan kelembagaan lokal Subak: Analisis konflik kepentingan sosial-ekonomi di Kabupaten Tabanan Bali. Disertasi, SPs IPB, Bogor.

Yusron E\& Edward (2000) Kondisi Perairan dan Keanekaragaman Hayati di Perairan Teluk Tomini Sulawesi Utara. Makalah dipresentasikan pada Seminar Nasional Pendayagunaan Sumber Daya Hayati dalam Pengelolaan Lingkungan, Tanggal 3 Juni, Fakultas Biologi Universitas Kristen Satya Wacana Salatiga.

Woyan I (2013) [Personal communication] Mei.

Zacot FR (2008) Orang Bajo Suku Pengembara Laut: Pengalaman Seorang Antropolog. Penerjemah Laure F.M., Pranoto I.B. Jakarta: Kepustakaan Populer Gramedia (KPG) bekerja sama dengan Ecolo Francaise d'Extreme-Orient dan Forum Jakarta-Paris. Terjemahan dari Peuple nomade de la mer: Les Badjos d'Indonesie.

Zainuddin S (2012) Berebut otoritas: Antara kilau emas versus konservasi (Studi kasus penambangan emas tradisonal pada komunitas masyarakat "Adat" Kaili di Tahura Poboya Kota Palu Provinsi Sulawesi Tengah). Disertasi, SPs IPB, Bogor. 